\title{
Understanding Vygotsky over Three Decades: a Critical Look
}

\author{
Jaan Valsiner ${ }^{1}$
}

Accepted: 22 September 2021 / Published online: 28 September 2021

(c) The Author(s), under exclusive licence to Springer Science+Business Media, LLC, part of Springer Nature 2021

The present Thematic Issue of our Journal is remarkable in its tracing the fate of ideas of one deeply interdisciplinary scholar of the beginning of the twentieth century-Lev Vygotsky (1896-1934) — to the integration of his ideas in the scholarship of the twenty-first century. In between these time periods of idea generation (by Vygotsky) and the integration of the ideas into new era of the social sciences (recent 30 years) remains a period of political suppression of these ideas (in the Soviet Union between 1936 and 1956) as well as the always difficult transfer of ideas from one society to another (Russia to Europe and onwards to North America). In that transfer interesting transformations and new confabulations occur. The migration of ideas is as complex as that of persons. It is embedded in the current political atmosphere-this is evident not only in the fate of the ideas of Vygotsky in his lifetime and after it, but also in their arrival and proliferation in the New World.

Back in 1993, at an international conference in Brazil, I was accused of "anti-semitism" by a leading North American child psychologist- because I had pointed to the positive educational value of Vygotsky's Jewish family environment. I was surprised and confused by such accusation-by emphasizing the value of being Jewish that led many of the ideas of Vygotsky I was only providing an insight to the roots of creativity of the scholar (cf Zavershneva \& van der Veer, 2018b). Only later did I begin to understand how complicated are the relations of people of Jewish backgrounds in the "melting pot" of the United States. Understanding takes time. And-overcoming of stigmatizations and unjustified dismissals takes even more time and tolerance.

The immediate trigger for my decision to organize the present section was the interesting time frame-30 years passing from our authoritative work on the intellectual and social history of Vygotsky's ideas (van der Veer \& Valsiner, 1991, 1996) this year, together with another milestone in the process of understanding the personal world of Lev Vygotsky on the basis of his discovered and unveiled Notebooks (Zavershneva \& van der Veer, 2017, 2018a, antedated by van der Veer \& Zavershneva, 2011).

Jaan Valsiner

jvalsiner@gmail.com

1 Aalborg University, Aalborg, Denmark 
In both Understanding and Notebooks, it is Rene van der Veer whose pivotal role has made Vygotsky's ideas ready for theoretical elaborations in the twentyfirst century. But will these ideas become further elaborated? Our new century is filled with new contextual demands on academia that were not there back in 1991 that often work towards superficiality of creating "popular figures" out of serious scholars and their publications. ${ }^{1}$ Our Understanding Vygotsky back in 1991 was an effort to stop such popularization avalanche. Looking back on that goal thirty years later it seems we failed, In 2020s the referencing of Vygotsky-or many other key thinkers of the twentieth century - seem to be framed by the dominance of clicking over thinking (Valsiner, 2018) that prioritizes short and sensationist sentiments over deep scholarly analyses and equally serious innovations of old ideas. This worry of twitterization of our social sciences let me to the idea of the present Thematic Section where different serious scholars who know and appreciate the ideas of Lev Vygotsky are brought together to discuss not only the past but possible futures of these ideas.

Understanding is a nice idea. Yet its appearance in the title of the book in 1991 was not our first authorial preference. Our suggested general title A quest for synthesis was vetoed by the publisher-on the grounds that including "synthesis" would let the book to become listed in data bases of chemistry and be forgotten by psychologists. We were not happy then, and a bit amused by the politico-linguistic intervention. As a compromise our preferred title ended up as a subtitle of the book,. Now-looking back-I find that the publisher was right then. In my other experiment with terminology-bringing the idea of catalysis into psychology as part of the main title (Cabell \& Valsiner, 2014) has led to a myriad of invitations to international conferences on catalytic chemistry as a keynote speaker that for obvious reasons were left unanswered. The mystique of labels seems to be easily picked up in our uses of dada bases. But what about the deep substance of ideas?

It is for the sake of answering the latter question that this Thematic Section is set up. I am most interested in the general question - what ideas have we really integrated with what theoretical systems in the work of our Journal, and the present analysis of Vygotsky's legacies is a part of this more general investigation that is going on.

\footnotetext{
${ }^{1}$ For instance, in the recent APA publication rules the publication place for books has been eliminated, leaving only the name of the publisher. Thus any reference to Sage Publications by these rules eliminates the information which team-in California, in London, or New Delhi-worked on the publication of the given book. This not only reduces the social value of books (and the actual editors who diligently worked on bringing them out) while the social value of journals (by increasing inclusion of DOI numbers) is artificially enhanced. This new practice reduces the precision of the arguments in published texts-especially in cases of historical writings where the town in which (by now extinct) book publishers once resided.
} 


\section{References}

Cabell, K. R., and Valsiner, J. (Eds.) (2014). The catalyzing mind: Beyond models of causality. Vol, 11 of Advances of Theoretical Psychology. Springer

Valsiner, J. (2018). The clicking and tweeting society: Beyond entertainment to education. In G. Marsico and J. Valsiner (Eds.), Beyond the mind (pp. 397-413) ). Information Age Publishers

van der Veer, R., \& Valsiner, J. (1991). Understanding Vygotsky: A quest for synthesis. Basil Blackwell.

van der Veer, R. \& Valsiner, J. (1996). Vygotsky: uma sintese. Edições Loyola, 1996; $2^{\text {nd }}$ printing in 1998] van der Veer, R., and Zavershneva, E,. (2011). To Moscow with Love: Partial Reconstruction of Vygotsky's Trip to London. IPBS: Integrative Psychological \& Behavioral Science, 45:458-474

Zavershneva, E., \& van der Veer, R. (Eds.). (2017). Zapisnye knizki L. S. Vygotskogio Izbrannoe. Izdatel'stvo Kamen.

Zavershneva, E., \& van der Veer, R. (Eds.). (2018a). Vygotsky's notebooks. A selection. Springer.

Zavershneva, E., \& van der Veer, R. (2018b). Not by bread alone: Lev Vygotsky's Jewish writings. History of the Human Sciences, 31(1), 36-55.

Publisher's Note Springer Nature remains neutral with regard to jurisdictional claims in published maps and institutional affiliations. 